\title{
Integration Interrupted \\ : The Impact of September 11, 2001
}

\author{
Lauren Lipovic \\ DePaul University, Chicago, USA \\ Matthew Sido \\ DePaul University, Chicago, USA \\ Animesh Ghoshal \\ DePaul University, Chicago, USA
}

\begin{abstract}
The economies of Canada and the United States, closely linked for many years, began a formal process of tighter integration with the Canada-United States Free Trade Agreement (1989) and North American Free Trade Agreement (1994). Due to the ease of border crossing, American and Canadian consumers took advantage of exchange rate variations to engage in cross-border shopping, implying a movement toward unified markets in the border regions. This process of integration was interrupted by tighter border controls after the terrorist attacks of 9/11. In this paper, we investigate the disruption of normal patterns of day tripping across the US-Canadian border. Using seasonally adjusted monthly data for the period 1994 2011, we show a robust relationship between the exchange rate and the flow of day trippers in each direction, implying cross-border shopping to be a major motive for day trippers. Using dummy
\end{abstract}

\footnotetext{
* Corresponding Author: Animesh Ghoshal; Department of Economics, DePaul University, 1 E. Jackson, Chicago, IL 60016, USA; Tel: +1 3123628781, Fax: +1 3123625452, E-mail: aghoshal@depaul.edu.

Co-Author: Lauren Lipovic; Department of Economics, DePaul University, 1 E. Jackson, Chicago, IL 60016, USA; Tel: +1 3123628781, Fax: +1 3123625452, E-mail: laurenlipovic@gmail.com.

Matthew Sido; Department of Economics, DePaul University, 1 E. Jackson, Chicago, IL 60016, USA; Tel: +1 3123628781, Fax: +1 3123625452, E-mail: matthew.sido@gmail.com.

Acknowledgements: We would like to thank Jeff Bergen, James Ciecka and Anthony Krautmann for helpful comments. Michael Morrone provided excellent research assistance.
} 
variables to represent the security measures enacted in September 2001, and the stricter documentation required after January 2008, we show that both sets of measures significantly reduced cross-border trips and thickened the border.

\section{JEL Classification: F15, F52}

Keywords: Cross-border Shopping, Economic Integration, Exchange Rates, Post 9/11 Security Measures

\section{Introduction}

The political and economic relations between Canada and the United States have historically been harmonious to an unusual degree among neighboring countries, ${ }^{1}$ and the border between the two has been open to an extent often held up as exemplary. ${ }^{2}$ After the attacks of September 11, 2001, however, US security measures were greatly stepped up, and this had a number of effects on travel and economic transactions across the border. Here, we examine the effect on day trips between Canada and the United States. In particular, we focus on the relationship between the exchange rate and the number of day trippers crossing the border in each direction, and how the relationship has been affected by the progressive tightening of border security in the period between 1994 and 2011.

The repercussions of the tragic events of thirteen years ago have a particular resonance in the context of a major focus of trade policy today-trade facilitation. As tariffs and traditional non-tariff barriers like quotas and voluntary export restraints have diminished in significance, it has become increasingly recognized that border bottlenecks constitute one of the remaining weak links of international trade, and the major international organizations have devoted considerable attention to trade facilitation, which seeks to reduce these barriers preventing countries from drawing full benefits

\footnotetext{
${ }^{1}$ While the principle enunciated by Myung-Gun Choo (2012) that neighboring coutries have historically engaged in conflicts is generally true, US-Canadian relations have been an exception.

${ }^{2}$ In the words of Winston Churchill, "That long frontier from the Atlantic to the Pacific Oceans, guarded only by neighbourly respect and honourable obligations, is an example to every country and a pattern for the future of the world." Quoted in Fried and Trezise (1984).
} 
from the advantages of open global markets. ${ }^{3}$ At the Bali ministerial meeting of the World Trade Organization (WTO) in December 2013, the first major multilateral trade agreement since the Uruguay Round focused on reducing red tape at borders. However, as Walsh (2006) has noted, addressing security concerns, while facilitating trade and minimizing border costs, is challenging.

It is well-known that borders are a major barrier to economic transactions. McCallum (1995), using a simple gravity model, showed that trade between Canadian provinces is more intense than trade between these provinces and states in the US of similar distance and economic size. More recently, Gopinath et al. (2011) used grocery store prices in the US and Canada and found strong evidence of market segmentation. However, those living close to the border are in a good position to take advantage of price differences for similar goods and services. Chandra et al. (2011), studying motivations for crossings in the US-Canadian border, concluded that they were strongly influenced by both arbitrage opportunities and by the costs of traveling to the border.

In the US-Canadian border, same-day travelers have for many years been much more numerous than overnight travelers. ${ }^{6}$ A major motivation of same-day travelers is shopping, and the economies of many border cities are heavily dependent on crossborder shopping. ${ }^{8}$ This is also true for the southern border of the US, but for reasons discussed later, we focus on the northern border.

\section{Exchange Rate and Currency Substitution}

The US-Canadian border has historically been characterized by (i) easy border

\footnotetext{
${ }^{3}$ See UN Economic Commission for Europe (2002), WTO (2004), OECD (2009), Roy and Banerjee (2010).

${ }^{4}$ "WTO approves global trade deal," Financial Times, December 7, 2013.

${ }^{5}$ If border crossing is costless, it is unlikely that large cross-border price differences will prevail for very long, as prices will rise in the face of increased demand. However, border costs have been well documented (Engel and Rogers 1996) and, moreover, we can have significant price differences on the two sides of a border, giving rise to arbitrage opportunities, since prices do not adjust immediately when exchange rates fluctuate.

${ }^{6}$ According to the US Bureau of Transportation and Statisitics, same day excursions accounted for $67 \%$ of travel between the US and Canada in the period 1990 1999.

${ }^{7}$ We use the terms same-day travelers and cross-border shoppers interchangeably though we recognize that not all same-day travelers are necessarily engaged in the purchases of goods or services.

${ }^{8}$ Half the retail sales in Laredo, Texas, are made by shoppers from Mexico (Black 2006).
} 
crossing, (ii) fully fluctuating exchange rates, with no attempt by either country to fix rates, and (iii) on the Canadian side, 70\% of Canadians living within 100 miles from the US border. We would, therefore, expect the amount of cross-border shopping to be related to relative prices, which would be affected by changes in the exchange rate, as well as inflation in each country.

In the period studied, inflation was under control in both the US and Canada, with prices rising by about the same rates in both countries. The exchange rate between the Canadian dollar, looney, ${ }^{9}$ and the US dollar, however, fluctuated quite a lot, with the value of the looney ranging between a low of 0.6251 US dollar in January 2002 and a high of 1.0468 US dollar in July 2011. We would expect Canadian cross-border shopping in the US to increase when the looney was strong (and the US dollar weak), and American cross-border shopping in Canada to increase when the American dollar was strong (and the looney weak). A study of the Canadian tourism industry (Roy 2005) does in fact find that a significant strengthening of the looney relative to the US dollar in the early 1990s resulted in a drastic increase in the number of day trippers from Canada to the United States.

We would also expect day trips to be affected by the cost of crossing, and carrying out transactions across the border. A feature that enhances cross-border shopping across the US-Canadian frontier is currency substitution. Currency substitution is defined as the use of a foreign currency instead of a domestic currency; for example, the use of US dollars in Canada. Currency substitution reduces the costs of cross-border shopping. If it is unnecessary to exchange currency at a bank or other financial institutions, a barrier to day tripping is eliminated. This also reduces the cost of exchanging any unspent foreign currency back to domestic currency after leaving a foreign country. Currency substitution is widespread in the US-Canada border region, thus strengthening the relationship between the currency exchange rate and cross-border shopping.

Retailers in border-towns have recognized the usefulness of accepting foreign currency since it can induce nearby foreigners to shop in their stores. A recent survey of Canadian communities in the Ontario-Michigan border found that $97 \%$ of retail stores accepted the American dollar (Pisani, Yoskowitz, and Brusa 2008). An earlier study of American retail stores in the border region between North Dakota and Maine showed that 70\% accepted the Canadian dollar (Pisani and Yoskowitz 2006). Currency substitution is popular because it is viewed as a convenience by day trippers and can be

\footnotetext{
${ }^{9}$ The Canadian dollar is often referred to as the looney, since the dollar coin has the image of the loon, a bird common in Canada. See, e.g., Roy (2005)
} 
conducted at a low cost to retailers. ${ }^{10}$

\section{Security Measures and Border Crossings}

Day trips for cross-border shopping are likely to be affected by the ease of crossing the border, and by the ease of bringing back purchased items. As the purpose of our study is to evaluate the impact of US national security policy on the relationship between currency exchange rate and cross-border shopping, we examine three distinct periods of time: Period One covers the implementation of North American Free Trade Agreement (NAFTA) on January 1, 1994 through September 10, 2001; Period Two, which encompasses September 11, 2001 until the US government increased identification requirements for entering the US on January 31, 2008; and Period Three, which involves the identification changes through August 31, 2011. We acknowledge that other security policies occurred within these periods, but our periods exemplify trends in US border policy in the 2000 s.

\section{A. From the start of NAFTA through September 10, 2001}

While economics informs us that free trade is desirable, politics often take precedence when determining trade policy. Regional trade agreements have historically proven to decrease the threat of war between countries and provide a means for countries to advance common economic interests (White 1998, Choo 2012). The three countries in North America have generally sought to maintain peaceful diplomatic relationships, as well as advance the economies of both countries simultaneously. To this end, the US and Canada agreed upon the Canada-US Free Trade Agreement (CUFTA) in 1989, which phased out a wide range of trade barriers. CUFTA was superceded by the NAFTA, which included Mexico, and was implemented on January 1, 1994. NAFTA eliminates duties and tariffs on goods, encouraging cross-border shopping since goods purchased in

\footnotetext{
${ }^{10}$ In both countries, retailers accepting the currency of the other country use in-house exchange rates which provide them with additional revenue. The average premium on the US side has been calculated at 7.7\% (Pisani and Yoskowitz 2006). Cross-border shoppers, presumably, are willing to pay this premium because of the convenience of using their own currency.
} 
one country can be imported into another freely. NAFTA also implies that the movement of individuals across borders, whether for business, shopping, or pleasure, should be free as well. ${ }^{11}$

We exclude Mexico because of the similarities between Canada and the United States. Both have long been each other's largest trading partners and are large developed economies with consumers that share similar preferences. ${ }^{12}$ Language and culture are largely consistent in border towns, with the possible exception of the province of Quebec. Accordingly, linguistic and cultural differences are not barriers that deter day trippers from passing from one country to the next. Moreover, unlike the US-Mexican border, which has long been subject to concerns about illegal immigration, ${ }^{13}$ the USCanadian border was extremely easy to cross, with little or no questioning by border authorities. Oral declarations of citizenship were accepted at the discretion of the officer, and only declared non-citizens needed to present identification (Heyman and Ackleson 2010). Crossing the border to shop during this period arguably had nearly the same convenience as driving from one town to the next in a home country. At the end of the last millenium, the border had become very thin, and the economies on each side of the border were closely integrated. Since NAFTA provides a period during which trade restrictions were at a minimum, this Period One from January 11994 to September 10 2001, serves as the baseline for our analysis.

\section{B. September 11, 2001 through January 30, 2008}

The terrorist attacks of September 11, 2001 dramatically altered the political landscape in the US. On the day of the attacks, the US completely closed its borders. In the period that followed, national security concerns began to impact trade between the US and Canada. ${ }^{14}$ The new security policies were often focused on individuals entering the US from foreign countries, and every vehicle attempting to enter was checked, with consequent delays. As such, we expect that the relationship between currency exchange rate and cross-border shopping was weakened by the policy changes the US imposed in

\footnotetext{
${ }^{11}$ We recognize that US-Canadian border crossings were relatively easy well before NAFTA, and use January 1994 as a convenient starting point for our observations.

${ }^{12}$ Trade between the US and Canada is the world's largest bilateral trade relationship.

${ }^{13}$ In September 2001, 331 US border patrol agents were deployed along the Canadian border, while 9061 were at the Mexican border (http://trac.syr.edu/immigration/reports/143/include/rep143table2.html).

${ }^{14}$ The immediate effects are well-covered in Goodrich (2012).
} 
response to the September $11(9 / 11)$ attacks.

\section{January 31, 2008 through August 2011}

On January 31, 2008, the United States government further thickened its borders. From this date forward, any individual attempting to enter the US via any mode of transportation was required to present valid identification. According to the 2008 policy, Canadians entering the US are required to present a valid passport, a certificate of Native North American status, an enhanced security driver's license, or a NEXUS card. Americans under the age of 18 and Canadians under the age of 19 must present a valid birth certificate (DHS 2008).

The United States has implemented measures to ease the ability of US and Canadian residents to travel between the two countries. ${ }^{15}$ This is especially important for day trippers. NEXUS cards were created with the objective of lowering financial and temporal costs of crossing the border. Individuals apply for a NEXUS card online and submit appropriate documentation along with a 50 US dollar processing fee. Applicants must also participate in an in-person interview before cards are mailed to them (DHS 2009). These requirements may make the NEXUS card less desirable than a passport, particularly since NEXUS cards only allow travel between the US and Canada.

\section{Data and Methodology}

We use three data sets for our analysis: the currency exchange rate of the Canadian dollar (CAD) per US dollar (USD), the consumer price index for each country, and the number of individuals crossing the US-Canada border by country of residence and mode of transportation for one-day trips. As mentioned earlier, we define three periods for our analysis. Period One, our baseline, spans January 1994 through August 2001. During this time, NAFTA was in effect and 9/11 had not yet occurred. Period Two spans over

\footnotetext{
${ }^{15}$ Trading goods was severely affected initially by huge and costly delays at US border points due to an emphasis on the physical inspection of cargoes (Walsh 2006). To mitigate the increased trade costs, the US government has entered into agreements with Canada for the pre-screening of cargo and expedited clearance. Our focus in this paper, however, is on cross-border travelers.
} 
September 2001 through to January 2008. We include September 2001 in this period for two reasons. First, our data is monthly. Second, the impact of 9/11 was immediate and noticeable in our data. For example, US day trips via automobile fell from 3,139,719 in August 2001 to 1,680,264 in September 2001. Period Three spans over February 2008 through to August 2011.

We expect that as the Canadian dollar appreciates, Canadians will be motivated to shop in the United States since the real purchasing power of the Canadian currency in the United States increases, and vice versa. Accordingly, we anticipate a negative relationship between the value of the Canadian dollar and the number of American day trippers. We expect this relationship to show changes over time. In Period One, we anticipate a strong and statistically significant relationship. We hypothesize that the policy changes of Period Two will decrease the number of day trippers relative to Period One. The impact of identification policy in Period Three should lead to further decreases in cross-border shoppers.

\section{A. Exchange rate}

Data on currency exchange rate were obtained from the Federal Reserve Board database- Foreign Exchange Rates G.5 Historical Data. We collected data on the average monthly spot exchange rate of the CAD/USD from January 1994 through August 2011 without altering the raw data.

\section{B. Border crossing data}

The bulk of our border crossing data was obtained from Statistics Canada, which has monthly data on the number of Canadian residents returning from the US by method of transportation, and the number of US residents entering Canada by method of transportation. We assume that the method of transportation Canadians used to return to Canada from the US is consistent with the method of transportation used to enter the US. The same assumption applies to US residents. We believe this is justifiable given the fact that these are one-day trips.

Through this database, we extracted data on the number of Canadian residents returning from the US and the number of US residents entering Canada from January 
1994 August 2011. Statistics Canada, a government agency, collects this information through the Frontier Counts Survey, a component of the International Travel Survey (ITS). For all methods of transportation other than airplanes, the agency collects data using a direct census rather than statistical sampling, heightening the accuracy of the data. Finally, Canadian officials check for errors and missing values in all reported data and contact the Canadian Border Services Agency ports when data gaps exist (International Travel Survey 2011).

\section{Visual Inspection of Trends}

\section{A. Exchange rate}

A graph of the monthly exchange rate shows the trend and fluctuations over time (Figure 1). In Period One, the USD was gradually appreciating relative to the CAD. Although there was significant variance around the general rise in the value of the USD during this time, the average appeared to be around 1.4 1.5 CAD for 1 USD. This trend continued until approximately January 2003. During Period Two, the USD depreciated to approximately $1 \mathrm{CAD}$. In Period Three, there was a strong appreciation of the USD from roughly June 2008 until March 2009, after which the USD fell back to around 1 CAD. 
Figure 1. Monthly spot exchange rate

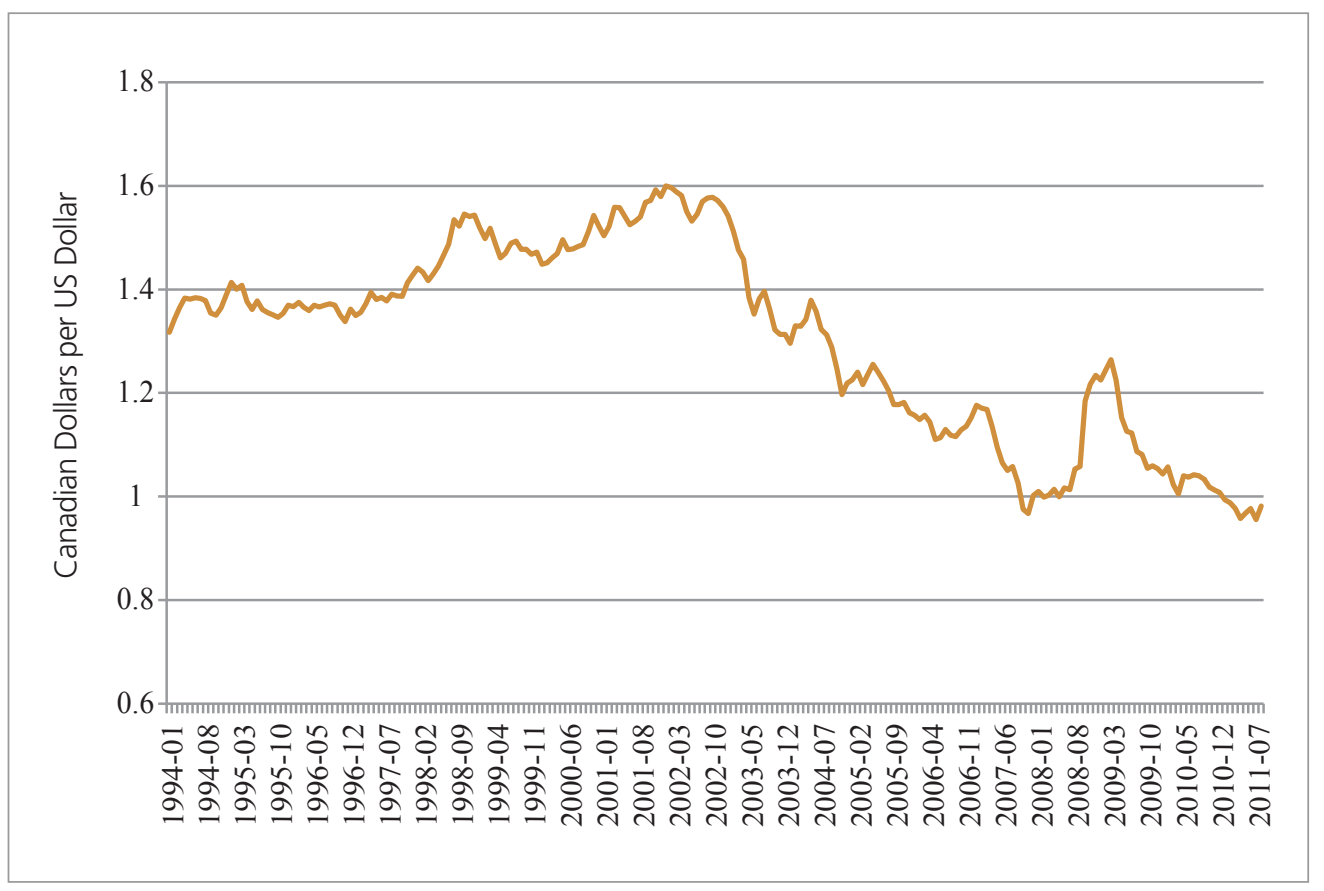

(Source) Federal Reserve Board Foreign Exchange Rates G.5 Historical Data.

\section{B. Automobiles and cross-border shopping}

Automobiles are the most prevalent form of transportation in the United States and Canada. Both prior studies (Roy 2005) and intuition suggest that automobiles should be the most significant form of transportation for day tripping. Other modes (trains, commercial and private airplanes, commercial and private boats, other vehicles, buses, and pedestrians) are highly unlikely to be used for cross-border shopping. An automobile is a practical method for transporting purchased goods from a foreign country back to a home country. The data indeed show that the number of individuals crossing the border by automobile far exceeds any other method of transportation. ${ }^{16}$ There is a strong component of seasonality to the data as demonstrated in Figures 2 and 3. In our subsequent analysis, the automobile data for both countries are seasonally adjusted.

\footnotetext{
${ }^{16}$ In 2010, for example, $88 \%$ of American day trippers to Canada used automobiles. The comparable figure for Canadian day trippers to the US was $98 \%$.
} 


\section{Figure 2. United States residents entering Canada}

(same day)

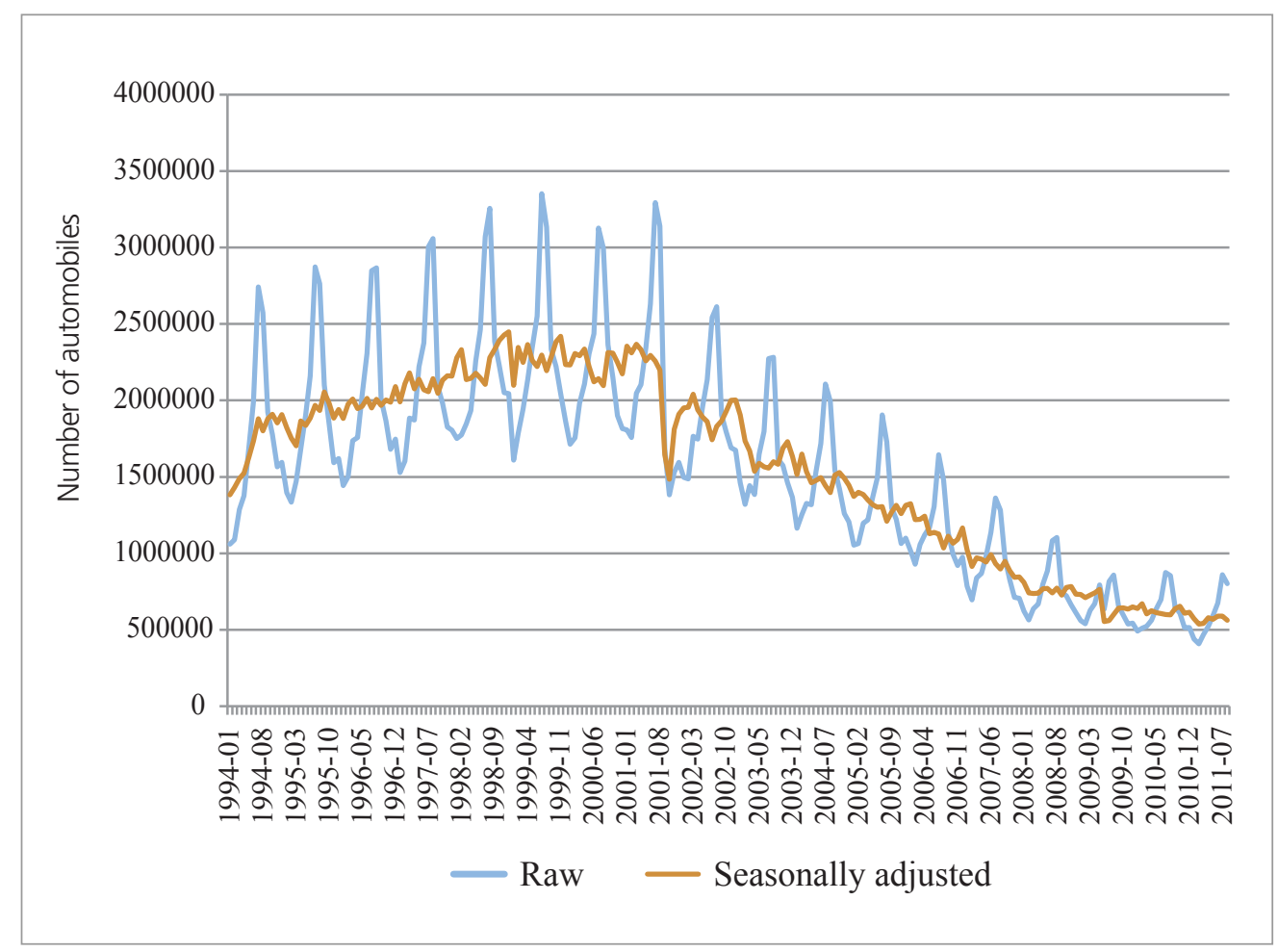

(Source) Statistics Canada, Table 427-0001 Number of international travellers (sic) entering or returning to Canada, by type of transport, monthly (persons), 11318 Series, October 21, 2011.

The number of US residents entering Canada by automobile is on the rise prior to September 11, and it begins to decline in Period Two (Figure 2). In Period One, US cross-border shopping is increasing and there is a large amount of seasonal variance during this period relative to the other periods. In Period Two, there is a significant decline in the number of US day trippers. In Period Three, the number of day trippers continues to decline, with a relatively small variance. 
Figure 3. Canadian residents returning from the United States

(same day)

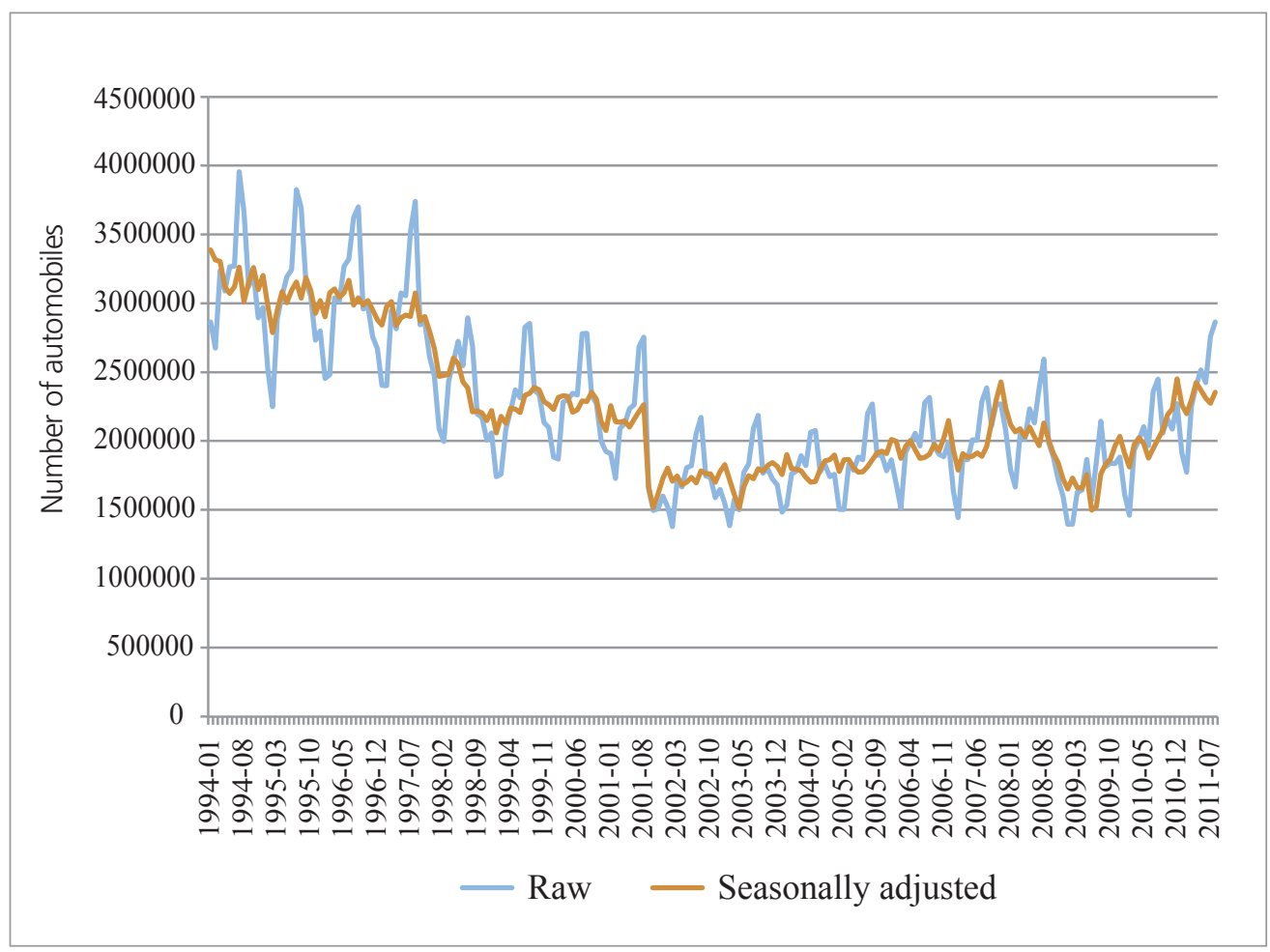

(Source) Statistics Canada, Table 427-0001 Number of international travellers (sic) entering or returning to Canada, by type of transport, monthly (persons), 11318 Series, October 21, 2011.

The number of Canadian residents returning from the US shows a somewhat different pattern (Figure 3). In Period One, Canadian cross-border shopping is falling, and there is more seasonal variance in this period than in the other two. In Period Two, day trips by Canadians are slightly increasing and the variance is diminishing. In Period Three, there is a large variance in Canadian day-trips; the number of day trips both decreases and increases in this period.

\section{Approximated demand curves}

Graphing monthly data on the number of day trippers in each period versus the currency exchange rate allows a visual representation of demand within periods. 
Furthermore, it allows for a comparison across the three periods and provides insight into how national security policy may have affected consumers' responsiveness to currency exchange rate.

\section{Figure 4. USD/CAD exchange rate $v$ s. United States day trips}

(1994 2001, Pre 9/11)

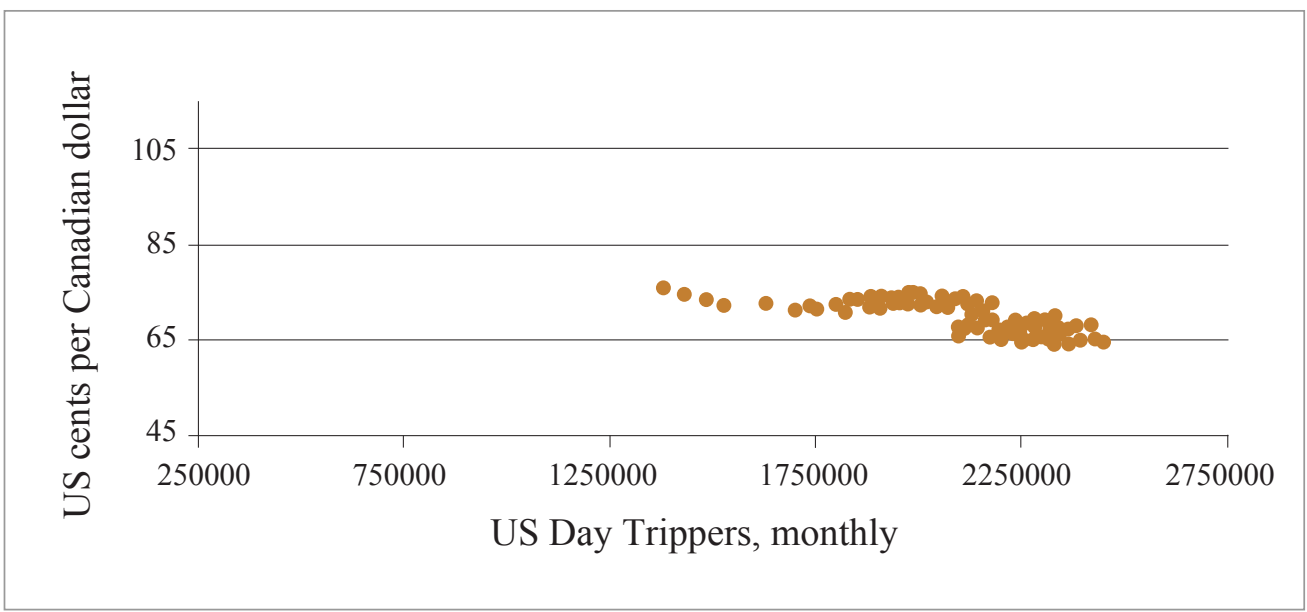

Figure 4 is a graph of the currency exchange rate vs. American day trips. The currency exchange rate is represented as US cents/CAD during Period One. The figure corresponds to a typical downward sloping demand curve, and demonstrates that day trippers were highly responsive to the exchange rate. As a US consumer's purchasing power increases in Canada, she is incentivized to take a one-day trip. 


\section{Figure 5. CAD/USD exchange rate vs. Canadian day trips}

(1994 2001, Pre 9/11)

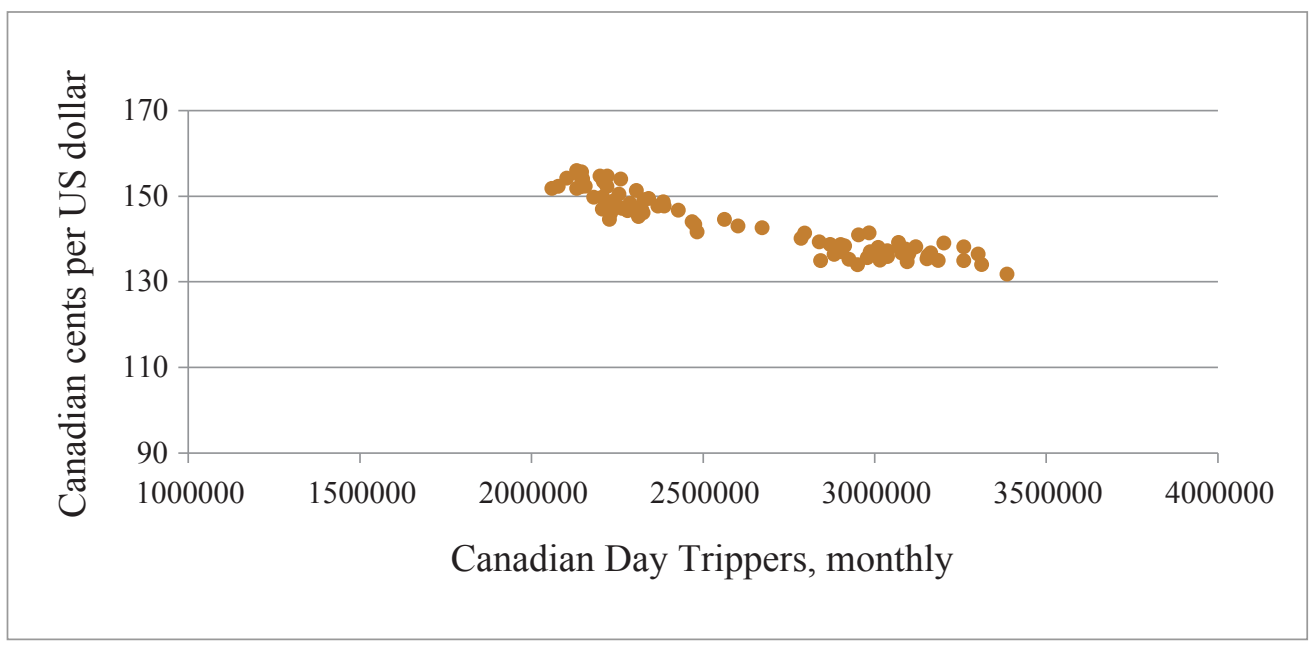

Figure 5 shows Canadian day trips as a function of the exchange rate, with the exchange rate represented as Canadian cents per US dollar. This, too, shows the expected inverse relationship. Pre-9/11, cross-border day trips in both directions clearly conformed to expectations about price responsiveness. 
Figure 6. USD/CAD exchange rate $v s$. United States day trips

(1994 2011, Pre and Post 9/11)

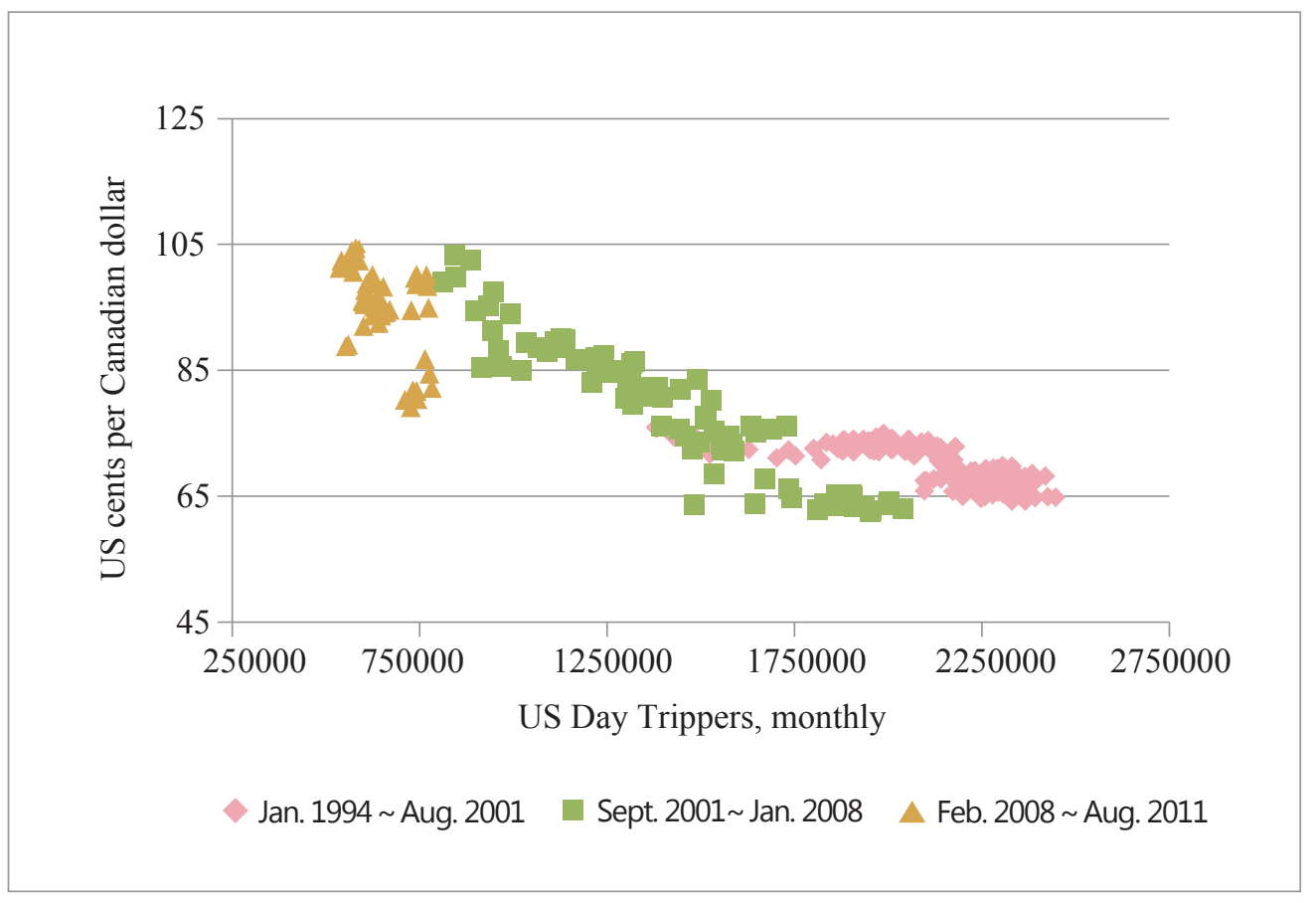

Figure 6 expands Figure 4 by adding data on US day trippers for Periods Two and Three. The data indicate a clear inward shift in Period Two, meaning a reduction in demand for day trips to Canada. While its slope of demand curve is steeper than Period One's, consumers still remained responsive to the exchange rate although less responsive than in Period One. In Period Three, not only have the number of day trips significantly decreased relative to the previous two periods, but the slope of the fitted demand curve is rather steep, and the fit appears to be poorer. This suggests that relationship between the exchange rate and cross-border shopping had deteriorated once strict identification requirements were instituted in 2008. 


\section{Figure 7. CAD/USD exchange rate vs. Canadian day trips}

(1994 2011, Pre and Post 9/11)

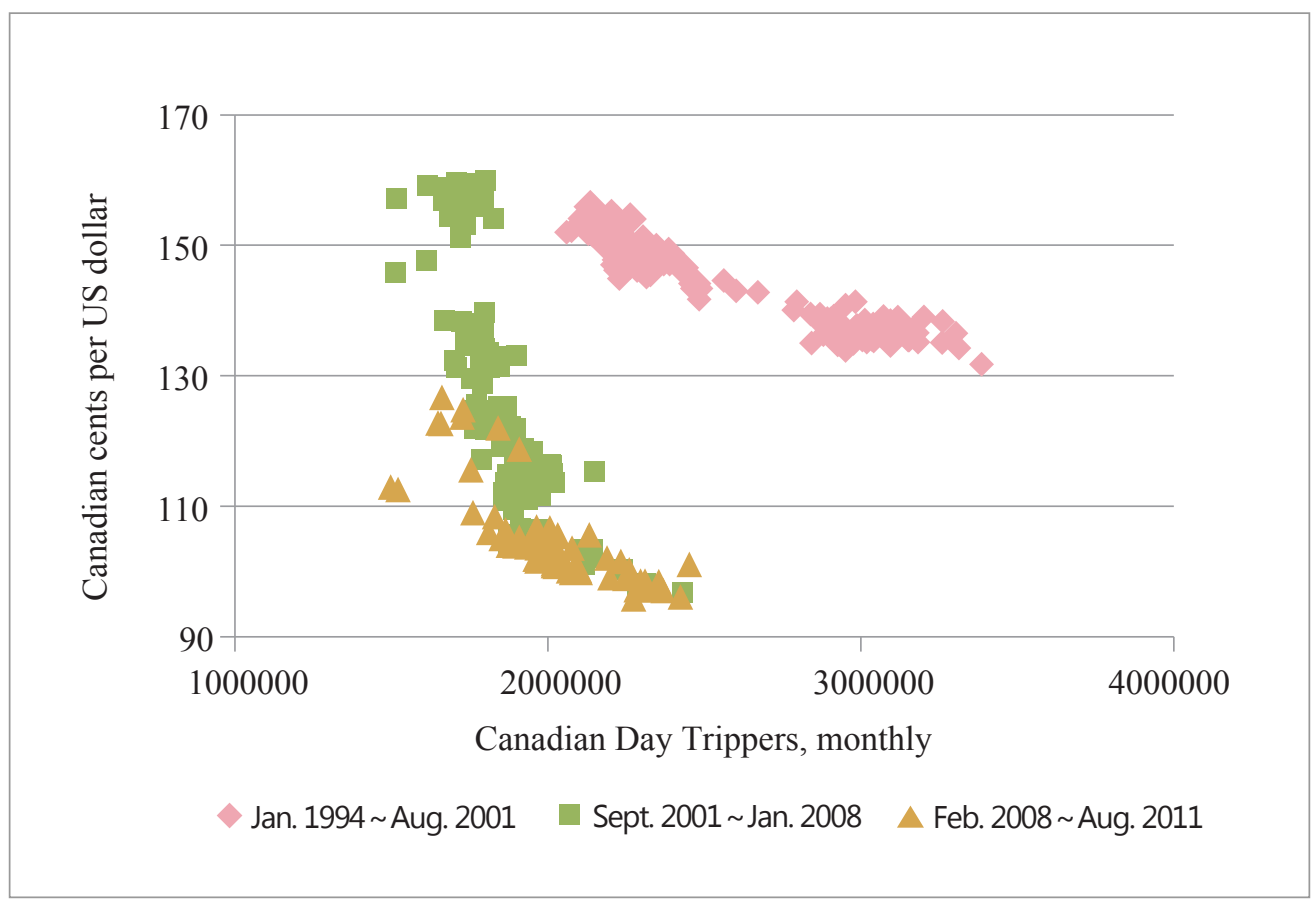

In Figure 7, we replicate this process whereas we expand Figure 5 by adding data on Canadian day trippers for Periods Two and Three. In Period Two, the number of day trips falls substantially relative to Period One, and the slope of the fitted demand line suggests that the responsiveness of consumers has decreased significantly. Finally, in Period Three, the number of day trippers overall is similar to that of Period Two. However, there appears to be a resurgence in the responsiveness of Canadian day trippers to the exchange rate as demonstrated by the slope of the fitted demand line in Period Three.

The results for both countries suggest that there is a correlation between US national security policy in the post-9/11 period and the number of day trippers, as well as the responsiveness of day trippers to currency exchange rates. For Period One, day trips from both countries are higher than in other periods, and the respective slopes of the fitted demand lines are relatively flat, suggesting responsiveness to the exchange rate. In Period Two, both countries experience a decline in day trips, as well as a less responsive fitted demand line. However, the countries differ in Period Three. The US day trippers 
fall in overall volume and the responsiveness declines further. Canadian day trippers remain around Period Two levels and actually become more responsive to exchange rate than in Period Two.

Figures 4 7 provide visual confirmation of our expectations regarding the impact of border security measures. We now proceed to statistical tests, and try to estimate the extent to which the enhanced border controls have affected cross-border day trips.

\section{Statistical Estimation}

\section{A. Real exchange rates}

Our statistical analysis is based on a simple formulation of a demand function, with the quantity demanded as a function of the relative price. The relative prices of American and Canadian goods and services depend on the real exchange rate, incorporating both the nominal exchange rate and inflation in each country. ${ }^{17}$ The real exchange rate, indicating the competitiveness of goods and services between two countries, can be defined in two ways, showing the relative price of foreign goods to domestic ones, or the inverse. In the following equation, we use the first

$$
R=\left(P^{*} / P\right) \cdot e
$$

Here, $P^{*}$ is the foreign price level, $P$ the domestic price level, and $e$ the nominal exchange rate showing the price of foreign currency in units of domestic currency.

From the Canadian perspective, if American prices rise more than Canadian prices, or if the US dollar rises against the Canadian dollar, the real exchange rate rises, making it less attractive for Canadians to buy goods and services from the US. Thus, the real exchange rate for Canadian day trippers is calculated as $R^{c}=\left(P^{u} / P^{c}\right) \cdot e^{c}$, where $P^{u}$ is the US Consumer Price Index (CPI), $P^{c}$ the Canadian Consumer Price Index (CPI), and $e^{c}$ is the exchange rate expressed as Canadian cents per US dollar.

\footnotetext{
${ }^{17}$ In Figures 4 through 7, we show the number of day trips against the nominal exchange rate, and ignore inflation. While this is acceptable for illustrative purposes, we believe that it is better to use real exchange rates for statistical testing incorporating changes in price levels.
} 
Similarly, from the American perspective, the real exchange rate is calculated as $R^{u}=\left(P^{c} / P^{u}\right) \cdot e^{u}$, where $P^{c}$ is the Canadian CPI, $P^{u}$ the US CPI, and $e^{u}$ the exchange rate expressed as US cents per Canadian dollar.

While including income would have made the model more complete, GDP data is only available on a quarterly basis, while the number of day trippers is available on a monthly basis, as is the average exchange rate. Using quarterly data would have meant a significant reduction in the number of observations. Moreover, we would expect decisions to make day trips across the border, if motivated by relative prices, to be responsive to more high-frequency variations in exchange rates than would be captured by quarterly data. ${ }^{18}$

\section{B. Models estimated}

In order to analyze the impact of policy on cross-border shopping between the US and Canada, we construct the following two OLS models:

Model 1:

$$
U S \_A U T O_{i}=\beta_{0}+\beta_{1} * R_{i}^{u}+\beta_{2} * D 2_{i}+\beta_{3} * D 3_{i}+\varepsilon_{\mathrm{i}}
$$

US_AUTO: US Residents Entering Canada, Automobile, Same Day.

$R^{u}$ : Real Exchange Rate facing US residents.

D2: Dummy variable, 1 in Period Two and Period Three, 0 otherwise.

D3: Dummy variable, 1 in Period Three, 0 otherwise.

$$
C A \_A U T O_{i}=\beta_{0}+\beta_{1}^{*} R_{i}^{c}+\beta_{2}^{*} D 2_{i}+\beta_{3}^{*} D 3_{i}+\varepsilon_{i}
$$

CA_AUTO: Canadian Residents Returning from the US, Automobile, Same Day.

$R^{c}$ : Real Exchange Rate facing Canadian residents.

D2: Dummy variable, 1 in Period Two and Period Three, 0 otherwise.

\footnotetext{
${ }^{18}$ We do not think that this exclusion presents a serious omitted variable problem. A quick calculation shows that the quarterly GDP of the US and Canada moved very closely with each other during the period, with a correlation coefficient of 0.9959 , while the pattern of day trippers from each country was quite different.
} 
D3: Dummy variable, 1 in Period Three, 0 otherwise.

In a second model, we introduce interaction terms between the exchange rate and the dummy variables. ${ }^{19}$

Model 2:

$$
\begin{aligned}
& U S \_A U T O_{i}=\beta_{0}+\beta_{1}^{*} R_{i}^{u}+\beta_{2}^{*} D 2_{i}+\beta_{3}^{*} D 3_{i}+\beta_{4}{ }^{*} R_{i^{*}}^{u} D 2_{i}+\beta_{5}{ }^{*} R_{i^{*}}^{u} D 3_{i}+\varepsilon_{i} \\
& C A \_A U T O_{i}=\beta_{0}+\beta_{1}{ }^{*} R_{i}^{c}+\beta_{2}{ }^{*} D 2_{i}+\beta_{3}{ }^{*} D 3_{i}+\beta_{4}{ }^{*} R_{i *}^{c} D 2_{i}+\beta_{5}{ }^{*} R_{i *}^{c} D 3_{i}+\varepsilon_{i}
\end{aligned}
$$

Real exchange rates are calculated as defined above, with the average nominal exchange rate for January 1994 as the base, and the CPI for each country rebased to January 1994. The two dummy variables above are defined using the start dates for Period Two and Period Three. The Period Two dummy variable is set to one beginning in September 2001 when tougher border security measures were implemented, and the Period Three dummy variable is set to one beginning in February 2008 when these measures were further tightened. Table 1 below shows the OLS regression results for the respective models.

\section{Results}

The results for Model 1 show that the relationship between the exchange rate and cross-border shopping is statistically significant and quite large. If the real exchange rate of the Canadian dollar rises by one US cent, the number of American day trippers decreases by 31,000 per month, ceteris paribus. On the other hand, if the real exchange rate of the US dollar rises by one Canadian cent, about 15,500 fewer Canadian day trippers travel to the United States.

Model 1 can be used to approximate the effect of enhanced security measures. The coefficients on Period Two and Period Three dummy variables are negative and highly significant for both US and Canadian travelers. For Americans, the 2001 policies reduced day trips by approximately 472,000 per month. The 2008 policies led to a

\footnotetext{
${ }^{19}$ We would like to thank the referee for this suggestion.
} 
further reduction of approximately 379,000 trips per month. For Canadians, the 2001 policies reduced day trips by almost one million per month. The 2008 policies further reduced day trips by approximately 179,000 per month.

In Model 2, which allows for interactions between the dummies and the exchange rate, we again see a significant relationship between the exchange rate and the number of day trippers. If the Canadian dollar has a real appreciation of one US cent, the number of American day trippers decreases by almost 47,000 per month, and if the US dollar appreciates by one Candian cent, there are about 43,000 fewer day trips by Canadians.

For US travelers, the coefficients of both Period Two and Period Three dummies are negative and significant, confirming a leftward shift in the demand relationship. The coefficients of both the interaction terms are positive, implying a reduction in the sensitivity to the exchange rate. For Canadian day trippers, the Period Two dummy is negative, and its interaction with the exchange rate positive, indicating a response similar to that of Americans. However, the coefficient of the Period Three dummy is positive, while its interaction with the exchange rate is negative, implying a flattening of the demand curve and an increased responsiveness to the exchange rate, compared to Period Two.

Since in Model 2 we have changes in both the slope and the intercept of the regression line, we cannot use the latter to get a direct estimate of the effects of the two security measures on the number of day trippers. However, an approximation can be made by calculating, in Equations (3) and (4), the (hypothetical) number of day trippers under the three regimes, at the mean exchange rate for the whole period. For US travelers, the mean exchange rate is 73.1559 cents per Canadian dollar, and for Canadians the mean exchange rate is 139.0305 cents per US dollar. ${ }^{20}$ Inserting these into the equations, and setting the dummies at appropriate levels, we have

For US travelers,

Period $1(D 2, D 3=0): \quad U S \_A U T O=1,802,909$

Period $2(D 2=1, D 3=0)$ : US_AUTO $=1,425,906$

Period $3(D 2, D 3=1)$ : US_AUTO $=738,682$

\footnotetext{
${ }^{20}$ It might be noted that the reciprocal value of 1.390305 is 0.719267 rather than 0.731559 . While it may appear puzzling at first glance, this is an example of the mathematical theorem that the arithmetic mean of a series of numbers is different from the harmonic mean, unless the numbers are identical.
} 
For Canadian travelers,

Period $1(D 2, D 3=0): \quad C A \_A U T O=3,117,877$

Period 2 ( $D 2=1, D 3=0): C A \_A U T O=1,841,812$

Period $3(D 2, D 3=1): \quad C A \_A U T O=1,541,368$

These approximations suggest that the 2001 border security measures reduced day trips by Americans by about 377,000 per month, while the tighter restrictions implemented in 2008 further reduced this by 687,000 per month. For Canadians, the corresponding numbers are 1,276,000 and 300,000, respectively.

\section{Differences between the US and Canadian day trippers}

The results above indicate an interesting difference between northbound Americans and southbound Canadians in the impact of tighter security measures. The Period Two security measures affected Canadian more than US day trippers. This is expected because the US implemented policies with the intent of tightening entry into the US, especially by foreigners. Accordingly, the impact fell largely on Canadian residents entering the US, rather than US residents returning to the US. The Period Three identification requirements, however, affected US day trippers more than Canadian day trippers. A likely reason for this is the larger percentage of Canadians with passports. From 2007 to 2010, the percentage of Canadian citizens holding active passports was $56.8 \%$ on average, whereas the percentage of Americans holding active passports was 30.2\% (Annual Report 2007 2011 and Passport Statistics 2011).

\section{Conclusion and Implication}

Almost all international transactions involve a frictional cost in both time and money, and onerous border crossing policies, just like a poorly functioning transportation system (Winston 2013), have a detrimental impact on economic activity. In this paper, we take a unique approach to a particular form of international economic activity: cross- 
border shopping between the United States and Canada. Using a parsimonious model, our research explores the relationship between day tripping tourism and public policy. Focusing on automobile travel, we find that national security policy implemented after 9/11 and in January 2008 both reduced the number of such tourists and affected the historically strong relationship between the exchange rate and cross-border shopping for both the US and Canada. We conclude that while there were some differences in the way the residents of each country were affected, public policy significantly affected crossborder shopping between the US and Canada, and in spite of attempts to ease travel through the issue of NEXUS cards, the security measures interrupted a long history of closer economic integration between the two neighbors.

Some policy implications can be drawn:

- The United States and Canada had been exemplary in the movement toward economic integration, with easy movement of goods and people across the border.

- Same day excursions have been predominant in border crossings.

- Until 2001, there was a clear relationship between the exchange rate and the number of day trips, suggesting that cross-border shopping for goods and services was a major motive of day trippers.

- Such cross border shopping served to unify markets in the border region, and served as a major boost to the economies of border cities.

- The security measures enacted by the United States after September 11, 2001, had profound repercussions on both sides of the border. Initially, movement of goods as well as people was severely reduced due to costly delays at border points.

- Trade facilitation agreements between the United States and Canada, allowing for pre-screening cargo and expedited clearance, have allowed trade in goods to fully recover. However, tourism by day trippers has remained well below the peak.

- Our estimates suggest that the security measures of 2001 and 2008 reduced American day trips to Canada by approximately between 850,000 and one million a month, while day trips by Canadians to the US fell by between 1.5 million and 1.8 million a month.

- On the Mexican frontier, the fortunes of border towns have declined sharply, mirroring the reduction in day trips. While the Canadian frontier is different, steps can be taken to ameliorate problems faced by border towns.

- Addressing security concerns while facilitating cross border travel is challenging 
but not impossible.

- The NEXUS card does not appear to have been as successful as hoped in alleviating the impact of border security measures.

- The US government might consider a less intrusive and expensive measure-prescreening those who cross the border frequently, and facilitating their travel. A precedent for this exists in the pre-approved status given by the Transportation Safety Administration to frequent flyers.

Received 20 February 2014 Received 25 March 2014. Accepted 14 December 2014

\section{References}

“2010 Census Data.” 2010 Census. U.S. Census Bureau. Web. 30 Oct. 2011. $<$ http://2010.census.gov/2010census/data/index.php>.

“Annual Report for 2007-2008." Passport Canada. Passport Canada, 10 Oct. 2008. Web. 01 Nov. 2011. <http://www.passportcanada.gc.ca/publications/ar_07.aspx?lang=eng>.

“Annual Report for 2008-2009.” Passport Canada. Passport Canada, 10 Nov. 2009. Web. 01 Nov. 2011. <http://www.passportcanada.ga.ca/publications/ar_08.aspx?lang=eng>.

“Annual Report for 2009-2010.” Passport Canada. Passport Canada, 27 Sep. 2010. Web. 01 Nov. 2011. <http://www.passportcanada.ga.ca/publications/ar_09.aspx?lang=eng>.

“Annual Report for 2010-2011.” Passport Canada. Passport Canada, 20 Oct. 2011. Web. 01 Nov. 2011. <http://www.passportcanada.ga.ca/publications/ar_10.aspx?lang=eng>.

Black, Thomas. "US Retailers Cash in as Mexican Shoppers Flock over Border". Bloomberg, Dec. 18, 2006. <http://www.bloomberg.com/apps/news?pid=newsarchive\& sid $=$ aROO3PUB3tSo $>$.

CANSIM (database). Last updated May 15, 2012. http://www.statcan.gc.ca/tablestableaux/sum-som/101/cst01/arts34-eng.htm (accessed October 21, 2011).

Chandra, Ambarish, Keith Head, and Mariano Tappata. "The Economics of Border Crossings. 1-40.” 2010. Web. 01 Oct. 2011. <http://strategy.sauder.ubc.ca/head/papers/ 
crossings.pdf $>$.

Choo, Myung-Gun., "What Does Integration Signify?" Journal of Economic Integration, 27 (2) (2012), 209-215.

"DHS: Frequently Asked Questions: New Border Crossing Procedures Beginning January 31, 2008." Department of Homeland Security | Preserving Our Freedoms, Protecting America. Department of Homeland Security, 18 Jan. 2008. Web. 15 Oct. 2011. <http://www.dhs.gov/xnews/releases/pr_1200677666905.shtm>.

"DHS: U.S. - NEXUS Program Description.” Department of Homeland Security. June 5, 2009. Web. 24 October 2011. <http://www.cbp.gov/xp/cgov/travel/trusted_traveler/ nexus_prog/nexus.xml>.

Engel, Charles, and John H. Rogers., "How Wide is the Border?" American Economic Review, 86(5) (1996), 1112-25.

Fried, Edward R. and Phillip Trezise, US-Canadian Economic Relations, The Brookings Institution, 1984.

"FRB H10: Data Download Program - Choose." Board of Governors of the Federal Reserve System. Federal Reserve Bank, 17 Oct. 2011. Web. 20 Oct. 2011. <http://www. federalreserve.gov/datadownload/Choose.aspx?rel=H10>.

Gopinath, Gita, P.-O. Gourinchas, C.-T. Hsieh and N. Li., "International Prices, Costs and Mark-up Differences." American Economic Review, 101(6) (2011), 2450-2486.

Goodrich, J.N., "September 11, 2001 Attack on America: A Record of the Immdediate Impacts and Reactions in the USA Travel and tourism Industry". Tourism Management, 23 (6) (2002), 573-580.

Heyman, Josiah and Jason Ackleson., "United States Border Scurity after 9/11. In John A. Winterdyk and Kelly W. Sundberg (Eds.)" Border Security in the Al Qaeda Era, , CRC Press (Taylor and Francis Group), 2010.

"International Travel Survey: Frontier Counts (ITS)." Statistics Canada. Statistics Canada, 18 Oct. 2011. Web. 25 Oct. 2011. < http://www.statcan.gc.ca/cgi-bin/imdb/ p2SV.pl?Function $=$ getSurvey\&lang $=\mathrm{en} \& \mathrm{db}=\mathrm{imdb} \& \mathrm{adm}=8 \& \mathrm{dis}=2 \& \operatorname{SDDS}=5005>$.

McCallum, J., "National Borders Matter: Canada-US Regional Trade Patterns." American Economic Review, 85 (3) (1995), 615-623. 
OECD, Overcoming Border Bottlenecks: The Costs and Benefits of Trade Facilitation, 2009.

"Passport Statistics." Welcome to Travel.State.Gov. U.S. Department of State, Bureau of Consular Affairs. Web. 01 Nov. 2011. <http://ravel.state.gov/passport/ppi/stats/ stats_890.html>.

Perry, Marc J. and Paul J. Mackun. "Population Change and Distribution: Census 2000 Brief." (2010): 1-7. Apr. 2010. Web. 29 Oct. 2011. <http://www.census.gov/ $\operatorname{prod} / 2001 \mathrm{pubs} / \mathrm{c} 2 \mathrm{kbr} 01-2 . p d f>$.

Pisani, Michael J. and David W. Yoskowitz., "Does the Canadian Dollar Travel South?" Mid-American Journal of Business 21 (2) (2006), 61-70.

Pisani, Michael J., David W. Yoskowitz, and Jorge Brusa. "The Retail Travels of the U.S. Greenback: A Comparative Study of Currency Substitution Along the U.S.-Canadian and U.S.-Mexican Borders.” International Trade Journal 22.3 (2008), 250-289.

"Reaching a Tipping Point? Effects of Post-9/11 Border Security on Canada's Trade and Investment." The Conference Board of Canada. Publication no. 187-07. Ottawa, 2007.

Roy, Francine. "Cross-border shopping and the loonie: Not what it used to be." (2007): 20-32. Dec. 2007. Web. 12 Oct. 2011. <http://www.statcan.gc.ca/pub/11-010-x/11-010x2007012-eng.pdf $>$.

Roy, Francine. "The Soaring Loonie and International Travel." Canadian Economic Observer 18 (2) (2005), 3.1-3.7.

Roy, Jayanta and Pritam Banerjee., "Connecting South Asia: The Centrality of Trade Facilitation for Regional Economic Integration", in S. Ahmed, S. Kelegama and E. Ghani (eds), Promoting Economic Cooperation in South Asia: Beyond SAFTA (2010), World Bank and Sage.

Statistics Canada. No date. Table 427-0001 Number of International Travelers Entering or Returning to Canada, by Type of Transport, Monthly (persons) (table).

United Nations Economic Commission for Europe.2002. Trade Facilitation: An Introduction to the Basic Concepts and Benefits.

United States. Office of the United States Trade Representative. Executive Office of the President. North American Free Trade Agreement (NAFTA). Web. 2 Oct. 2011. 
$<$ http://www.ustr.gov/tradeagreements/free-trade-agreements/north-american-free-tradeagreement-nafta>.

United States Bureau of Transportation Statistics. No date. Passenger Travel between the United States and Canada. http:/www.rita.dot.gov/bts/sites/rita.dot.gov.bts/files/ publications/north_american_trade_and_travel_trends/html/table_10.html.

Walsh, James T. 2006., "New Customs”, Finance and Development, 43 (1), 48-51.

White, Timothy J., "American Participation in NAFTA: Economic Incentives, Influence, andDomestic Politics.” International Journal on World Peace, 15 (4) (1998), 43-59.

Winston, Clifford., "On the Performance of the U.S. Transportation System: Caution Ahead.” Journal of Economic Literature, 51(3) (2013), 773-824.

WTO, 2004. Doha Development Agenda, Text of "July Package”, Annex D. 


\begin{tabular}{|c|c|c|c|c|c|c|c|c|c|c|c|c|c|c|c|}
\hline \multirow{3}{*}{ 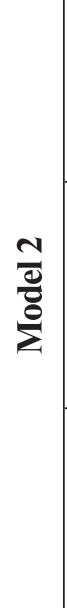 } & $\begin{array}{l}\frac{0}{3} \\
\frac{\pi}{\pi} \\
\sum^{1}\end{array}$ & 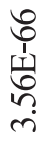 & 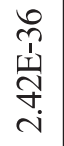 & $\begin{array}{c}\infty \\
0 \\
\text { 站 } \\
\infty \\
- \\
-\end{array}$ & $\begin{array}{l}\frac{a}{1} \\
\text { 立 } \\
\hat{a}\end{array}$ & $\begin{array}{l}= \\
\bar{\Xi} \\
8 \\
0\end{array}$ & $\begin{array}{l}n \\
\frac{n}{1} \\
n \\
n \\
n \\
n\end{array}$ & \multirow{3}{*}{ 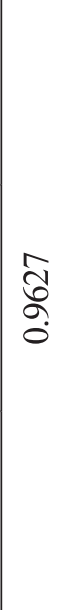 } & 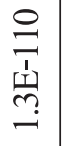 & 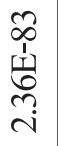 & \begin{tabular}{l}
$m$ \\
\multirow{1}{1}{} \\
0 \\
$\vdots$ \\
$=$
\end{tabular} & $\begin{array}{l}\exists \\
7 \\
\text { ñ } \\
n \\
r\end{array}$ & 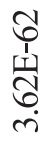 & 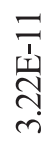 & \\
\hline & 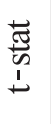 & \begin{tabular}{l}
\multirow{i}{a}{} \\
$\ddot{d}$
\end{tabular} & $\begin{array}{l}\tilde{f} \\
\stackrel{\tilde{r}}{T}\end{array}$ & $\begin{array}{l}\hat{\infty} \\
\dot{1} \\
\dot{1}\end{array}$ & 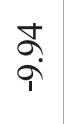 & $\begin{array}{l}\text { मे } \\
\text { mे }\end{array}$ & $\underset{\infty}{\forall}$ & & $\begin{array}{l}0 \\
\dot{b} \\
\dot{t}\end{array}$ & 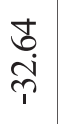 & $\begin{array}{l}\stackrel{8}{0} \\
\infty \\
\stackrel{1}{1}\end{array}$ & $\hat{\infty}$ & $\begin{array}{l}\vec{\sim} \\
\stackrel{\sim}{ }\end{array}$ & $\frac{\sigma}{\widehat{C}}$ & \\
\hline & 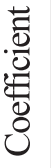 & 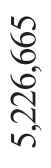 & $\begin{array}{l}\overline{8} \\
\infty \\
0^{\circ} \\
+1\end{array}$ & 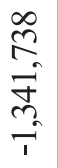 & 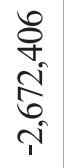 & $\begin{array}{l}\infty \\
\stackrel{\infty}{=}\end{array}$ & $\begin{array}{l}\frac{0}{n} \\
\text { त̂ }\end{array}$ & & $\begin{array}{l}\hat{\infty} \\
0 \\
\infty \\
\delta \\
0 \\
0\end{array}$ & 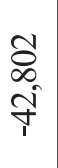 & 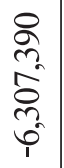 & $\begin{array}{l}\hat{\sigma} \\
\mathfrak{n} \\
\hat{n}\end{array}$ & $\frac{2}{\sigma_{0}^{\circ}}$ & \begin{tabular}{l}
+ \\
2 \\
$m$ \\
\multirow{1}{*}{}
\end{tabular} & \\
\hline \multirow{3}{*}{$\begin{array}{l}\bar{\sigma} \\
\frac{0}{0} \\
\sum\end{array}$} & $\begin{array}{l}\frac{0}{3} \\
\frac{\pi}{\pi} \\
\sum_{1}^{1}\end{array}$ & 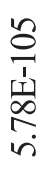 & $\begin{array}{l}n \\
n \\
n \\
0 \\
0 \\
\dot{y}\end{array}$ & 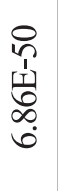 & 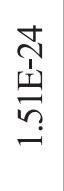 & & & \multirow{3}{*}{$\begin{array}{l}\stackrel{+}{2} \\
\stackrel{0}{0}\end{array}$} & 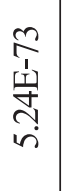 & 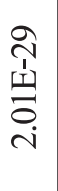 & 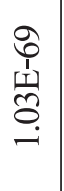 & $\begin{array}{l}\bar{R} \\
\hat{\delta} \\
\delta \\
0\end{array}$ & & & \\
\hline & 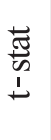 & $\underset{\stackrel{+}{+}}{\stackrel{+}{+}}$ & $\frac{\widetilde{\sigma}}{\widehat{T}}$ & $\begin{array}{l}\mathscr{\infty} \\
\stackrel{0}{0} \\
\frac{1}{1}\end{array}$ & $\begin{array}{l}\hat{6} \\
\underset{7}{7}\end{array}$ & & & & $\begin{array}{l}\stackrel{0}{ } \\
\infty \\
\text { ָे }\end{array}$ & 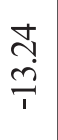 & 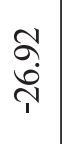 & $\underset{r}{\tilde{T}}$ & & & \\
\hline & 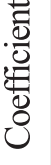 & 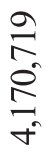 & $\frac{\stackrel{\rho}{0}}{\overrightarrow{1}}$ & 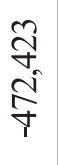 & $\begin{array}{l}\infty \\
\infty \\
\infty \\
\infty \\
n\end{array}$ & & & & 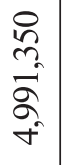 & $\begin{array}{l}n \\
n \\
n \\
n \\
1\end{array}$ & $\begin{array}{l}n \\
\infty \\
\tilde{n} \\
\frac{1}{1}\end{array}$ & $\begin{array}{l}2 \\
\infty \\
\infty \\
\infty \\
1\end{array}$ & & & \\
\hline & & $\begin{array}{l}\widetilde{8} \\
\frac{0}{3} \\
\vdots\end{array}$ & 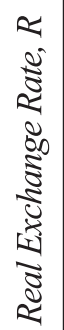 & 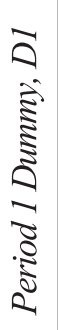 & 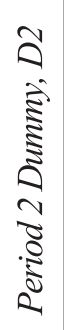 & 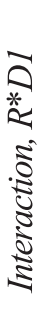 & 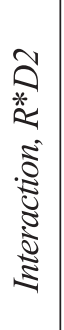 & N $\propto$ & 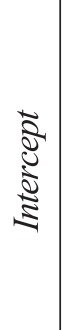 & 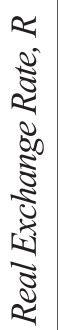 & 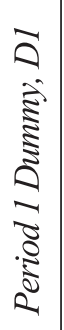 & 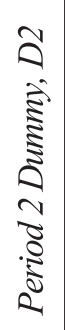 & 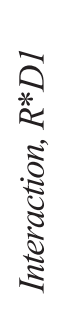 & 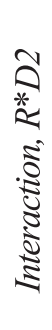 & \\
\hline \multicolumn{9}{|c|}{ 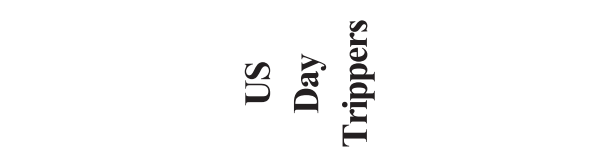 } & \multicolumn{6}{|c|}{ 疍 } & \\
\hline
\end{tabular}

